
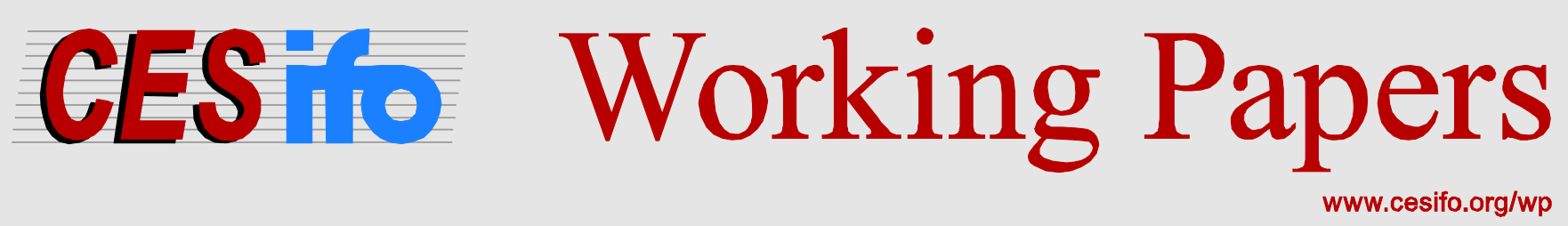

\title{
Economy Wide Impact of the Trade Integration between Japan and India: A Computable General Equilibrium Analysis
}

\author{
Biswa Nath Bhattacharyay \\ Kakali Mukhopadhyay
}

CESIFO WORKING PAPER NO. 4557

CATEgory 8: Trade Policy

DECEMBER 2013

\footnotetext{
An electronic version of the paper may be downloaded

- from the SSRN website:

- from the RePEc website:

- from the CESifo website:

www.SSRN.com

www.RePEc.org

www.CESifo-group.org/wp
}

\section{CESifo}




\title{
Economy Wide Impact of the Trade Integration between Japan and India: A Computable General Equilibrium Analysis
}

\begin{abstract}
Japan and India signed the much-awaited Comprehensive Economic Partnership Agreement (CEPA) on 16th February 2011. The CEPA will eliminate tariff on goods that account for $94 \%$ of their two way trade over ten years and will boost bilateral trade and investment. Indian exports which were subject to rigid standards will find it easier to enter Japanese markets. On the other hand, reduction of tariffs would help Japanese exports to exploit the growing Indian market. In this background, the study evaluates the economy wide impact of the proposed CEPA between India and Japan at 2020. The study has used a widely recognized global Computable General Equilibrium (CGE) model. Results show a marginal increase in output growth for India and Japan in 2020 after tariff reduction compared to Business as Usual (BAU) scenario. A marginal export growth is expected for both the countries compared to BAU 2020. A fair amount of trade creation within these two countries is expected to occur. India would likely to increase its export to Japan by I8.25\%, while for Japan it will be only $4.65 \%$ by 2020 . The proposed CEPA will also improve the welfare of both the countries at 2020. An important finding of the study is that in spite of tariff liberalization in agriculture sector which is protected through stringent tariff and non-tariff barriers, Japan will witness considerable welfare gain. On the whole, it reflects that compared to Japan, India is expected to gain more during the 2010-2020 from the successful implementation of CEPA. The triple disasters (earthquake, Tsunami and radiation leaks) in Japan in March 2011 will have short-term negative impacts on the economy but is unlikely to affect the expected gains from CEPA between India and Japan. The short negative impact may be significant but in the long-run Japanese economy will expand through reconstruction efforts and return to productive activities - leading towards enhanced economic cooperation between the two countries.

JEL-Code: F100, F200, Q100, Q400, R400.
\end{abstract}

Keywords: India, Japan, Asia, economic cooperation, trade and investment, Free Trade Agreement, Comprehensive Economic Partnership Agreement, CGE Model.

\author{
Biswa Nath Bhattacharyay* \\ Visiting Professor, Institute of International \\ Economy, University of International \\ Business and Economics, Beijing (PRC) \& \\ Adjunct Professor, Fore School of \\ Management, New Delhi (India) \\ dr_biswa@yahoo.com
}

\author{
Kakali Mukhopadhyay \\ Senior Researcher, Department of \\ Agricultural Economics, McGill University, \\ Montreal (Quebec / Canada) \\ kakali.mukhopadhyay@mcgill.ca
}

This is a revised version of the paper presented at the 19th International Input-Output Conference of the International Input-Output Association held at the Alexandria VA, USA, from 13-17 June, 2011.

*The author was advisor, Office of Regional Economic Integration, Asian Development Bank, Manila during the preparation of the paper. 


\title{
Economy Wide Impact of the Trade Integration between Japan and India: A Computable General Equilibrium Analysis ${ }^{3}$
}

\author{
Biswa Nath Bhattacharyay ${ }^{4}$ \\ Visiting Professor, Institute of International Economy, University of International \\ Business and Economics, Beijing, and \\ Adjunct Professor, Fore School of Management, New Delhi \\ Kakali Mukhopadhyay \\ Department of Agricultural Economics, McGill University, Montreal.
}

\section{Introduction}

India and Japan have a long history of trying to strengthen trade relations, starting with the Agreement on Commerce between India and Japan in 1958. The overall India-Japan trade talks on bilateral trade and investment began in 1978 (Economy Watch, 2008).

A Joint Study Group was formed in April 2005 during Japanese Prime Minister Junichiro Koizumi's visit to India. This is in line with Japan's intention of strengthening its economic partnerships with Asian countries through expansion of trade and investment and through harmonizing common rules in various fields and facilitation of the movement of people in order to develop and strengthen the competitiveness of the entire Asian region. By June 2006, the report of the India-Japan Joint Study Group was submitted. This study concluded that there is a huge untapped potential to further develop and diversify the economic engagement between India and Japan (Ministry of Finance, India and Ministry of Foreign Affairs, Japan, 2006).

As a result, the two countries negotiated on a traditional bilateral FTA consisting of tariff elimination and reduction at the core with the aim of realizing a (Comprehensive) Economic Partnership Agreement (CEPA or EPA) in a way consistent with the World Trade Organization (WTO) principle. While the EPA/CEPA negotiation between India and Japan is ongoing, the two leaders of both countries in 2006 declared the "India-Japan Special Economic Partnership Initiative" (SEPI). This initiative is meant to promote the enhancement of investment from Japan to India and help develop India's infrastructure and manufacturing capacity. The main

\footnotetext{
${ }^{3}$ This is a revised version of the paper presented at the $19^{\text {th }}$ International Input-Output Conference of the International Input-Output Association held at the Alexandria VA, USA, from 13-17 June, 2011.

${ }^{4}$ The author was advisor, Office of Regional Economic Integration, Asian Development Bank, Manila during the preparation of the paper.
} 
components of SEPI include (i) the development of infrastructure and promotion of manufacturing, trade and investment; (ii) human resource development for promotion of manufacturing; (iii) science and technology initiative; (iv) people-to-people exchanges; and (v) regional and multilateral cooperation (Ministry of Finance, India and Ministry of Foreign Affairs, Japan, 2006).

Negotiations for a CEPA covering a wider range of issues including market access in trade in goods, rules of origin, custom procedures, trade in services, investment, intellectual property, non-tariff barriers, competition etc are currently underway. There have been seven rounds of negotiations. In the fifth round held in New Delhi in January 2008, both sides agreed on the modalities of the negotiations for market access of trade in goods and decided to proceed to exchange of offers (Embassy of India in Japan, 2008).

The EPA/CEPA should be defined as a framework of institutional arrangements that can achieve deeper economic cooperation than a simple FTA, encompassing all aspects of bilateral economic relations such as the liberalization of trade in goods and services, investment, economic cooperation and other areas of cooperation for mutual benefit. So the India-Japan EPA/CEPA may cover, but may not be limited to: (i) trade in goods; (ii) trade in services; (iii) measures for trade promotion; (iv) promotion, facilitation and liberalization of investment flows; and (v) measures for promoting economic cooperation in identified sectors (Kawai, Bhattacharya and Mukhopadhyay, 2011).

Liberalization of trade in goods under the EPA/CEPA would improve trade flows between the two economies and promote further intra-industry and inter-industry trade. An EPA/CEPA will also serve as a building block for regional economic integration on a larger scale. The case for India-Japan EPA/CEPA essentially rests on complementarities of the partner economies (Kawai, Bhattacharya and Mukhopadhyay, 2011).

In October 25, 2010, leaders of Japan and India declared the successful conclusion of negotiations for the Comprehensive Economic Partnership Agreement between the two countries. Finally, Japan and India signed the much-awaited Comprehensive Economic Partnership Agreement on $16^{\text {th }}$ February 2011 that would abolish duties on more than $90 \%$ of trade for 10 years. The deal would eliminate tariffs on 90 percent of Japanese exports to India, such as auto parts and electric appliances, and 97\% of imports from India, including agricultural and fisheries products, until 2021. India and Japan have set a target of achieving \$25 billion worth of bilateral trade by 2014 from the present $\$ 10.3$ billion. India stands to gain significantly through this agreement and 90 per cent of tariff lines are covered while Japan has covered 5 per cent more lines than India. On a trade value basis, while Japan has agreed to 97 per cent tariff reduction in trade in goods, India has consented for 90 per cent duty abolition.

On several farm products, forest items and marine products such as lumbers, shrimps and prawns, durian and asparagus, there would 3-6 per cent tariff reduction immediately after the agreement comes into force by April 1. In other agriculture and marine commodities such as 
black tea, frozen octopus, capsicum, curry and sweet corn, Chinese yam, peach and strawberries, tariffs would be gradually reduced in the next 7-10 years. In industrial goods, elimination of duties in auto parts such as diesel engines and gear boxes would be done over a period of 10 years. Similarly, duties would be reduced by about 94 per cent in DVD players, video cameras and steel sheets, plates and alloys within the next 5-10 years. As the majority of Japan's non-agricultural tariff lines will see immediate duty elimination for exports from India, with a strategic approach, India can significantly improve its share in Japan's total imports from the existing low level of 0.7 per cent.

Towards this end, the study attempts to evaluate the benefits of proposed CEPA between Japan and India. The current paper will estimate the economy wide impact of CEPA between Japan and India.

The paper is organized as follows: section 2 deals with the trend and patterns of trade between India and Japan. It covers the total bilateral trade between countries as well as commodity trade. Section 3 reviews some literatures. Section 4 calibrates the GTAP framework which has been used to undertake the analysis. Section 5 discusses the economy wide impact of CEPA. Section 6 concludes the paper with some impact in Japan due to recent earthquake.

\section{Trends and Patterns in Trade of India and Japan}

India's trade as a percentage of GDP more than tripled from 16 percent in 1990 to 55 percent in 2009 whereas for Japan, it increased from 20 percent to 34 percent during the same period (Table 1).

Table 2 shows the increasing pattern of India's and Japan's trade. India illustrates significant increase in total trade as 2009 level registered a ten-fold increase compared to 1990 level (from US $\$ 42$ billion in 1990 to US\$ 421 billion in 2009) whereas Japan doubled its total trade from US\$523 billion to US\$1 trillion during the same period.

There has been a significant increase in Japanese trade (both import and export) with ASEAN countries and PRC. On the other hand, its trade with the US and European Union (EU) exhibited only a modest increase. While Japanese trade with India almost doubled in 2009 compared to 2000 level, it remains very small compared with that with other countries over the last nineteen years (1990-2009) exhibiting significant potential for trade expansion(Kawai, Bhattacharya and Mukhopadhyay, 2011). 
Table 1: Key Economic Indicators of India and Japan: 1990-2009

\begin{tabular}{|c|c|c|c|c|c|c|}
\hline \multirow{2}{*}{ Country } & \multicolumn{3}{|c|}{ India } & \multicolumn{3}{|r|}{ Japan } \\
\hline & 1990 & 2000 & 2009 & 1990 & 2000 & 2009 \\
\hline Trade (\% of GDP) & 16 & 27 & 55 & 20 & 21 & $34^{*}$ \\
\hline Trade in services ( $\%$ of GDP) & 3 & 8 & NA & 4 & 4 & 5 \\
\hline Exports of goods and services (\% of GDP) & 7 & 13 & 25 & 10 & 11 & $18^{*}$ \\
\hline Imports of goods and services (\% of GDP) & 9 & 14 & 30 & 10 & 10 & $16^{*}$ \\
\hline
\end{tabular}

Source: WB World Development Indicators, 2010; IMF International Financial Statistics 2010; *2007 data

Table 2: Total Trade of India and Japan: 1990-2009 (US\$ Million)

\begin{tabular}{lcccccc}
\hline & \multicolumn{3}{c}{ India } & \multicolumn{3}{c}{ Japan } \\
\cline { 2 - 7 } Trade & $\mathbf{1 9 9 0}$ & $\mathbf{2 0 0 0}$ & $\mathbf{2 0 0 9}$ & $\mathbf{1 9 9 0}$ & $\mathbf{2 0 0 0}$ & $\mathbf{2 0 0 9}$ \\
\hline Exports & $17,969.10$ & $42,379.30$ & $164,933.00$ & $287,581.00$ & $479,249.00$ & $580,719.00$ \\
Imports & $23,579.60$ & $51,522.90$ & $256,239.00$ & $235,368.00$ & $379,511.00$ & $550,530.00$ \\
\hline
\end{tabular}

Source: CEIC Database, 2010

In terms of the shares of world trade, Japan's import from India decreased from 0.9 percent in 1990 to 0.7 percent in 2009 while its export to India increased from 0.6 percent to 1.1 percent during the same period.

India's total trade with Japan almost tripled from 1990 to 2009 and this can be attributed to the trade policy improvements made by India. However, it is still very low compared with its major trading partners such as EU, US, PRC and ASEAN. India's trade expansion with PRC has been remarkable and by 2009 PRC became India's second biggest trading partner(Kawai, Bhattacharya and Mukhopadhyay, 2011). 


\subsection{India-Japan Bilateral Trade}

For a long period, especially until the 1990s, India-Japan bilateral trade was stagnant without exceeding the US $\$ 4$ billion mark (Rajamohan et al., 2008). This may be due to the fact that India's trade was primary directed towards Europe and the US markets because of its cultural and colonial past. The stagnation in the economic relationship between India and Japan was finally broken when India embarked on major economic reforms by liberalizing the country's economy and adopting an open-door policy that led to a gradual acceleration of bilateral business relationships in 1991(Kawai, Bhattacharya and Mukhopadhyay, 2011).

Figure 1 shows the steady rise of bilateral trade between the two countries. India-Japan trade almost doubled in every ten year period. Japanese export to India slightly decreased in 2009 from 2000 level but still increased compared to that in 1990 while import from India consistently increased $^{5}$. Despite robust growth in the overall trade of both India and Japan with the world in recent years, the bilateral trade between the two countries has remained quite low (Rajamohan et al. 2008).

The major items exported from India to Japan include mineral fuels and oil, gems and jewelry, ores, slag and ash, marine products, petroleum, cotton yarn, and fabrics. The major Items imported to India from Japan include machinery (e.g. transport equipment and machine tools), electrical machinery, electronic goods, and iron and steel products (ICRIER, 2008).

As shown in Table 3, refined petroleum products, iron ores, and jewelries are the top three commodities exported by India to Japan in 2008. Meanwhile, iron steel, machine tools, and engines are the top three commodities which Japan supplies to India in 2008 (Table 4).

\footnotetext{
${ }^{5}$ Note that disparities in data between Japan's exports to India and India's imports to Japan are observed.
} 
Figure 1 Bilateral Trade between India and Japan: 1990-2009
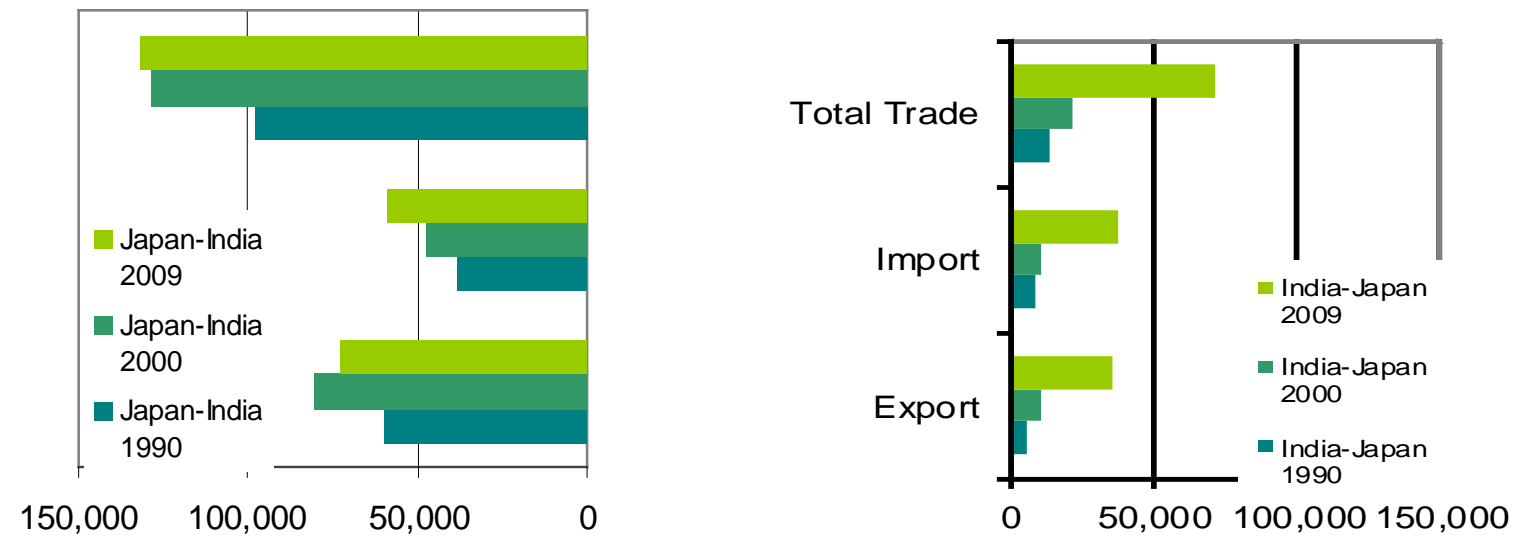

in US\$ M

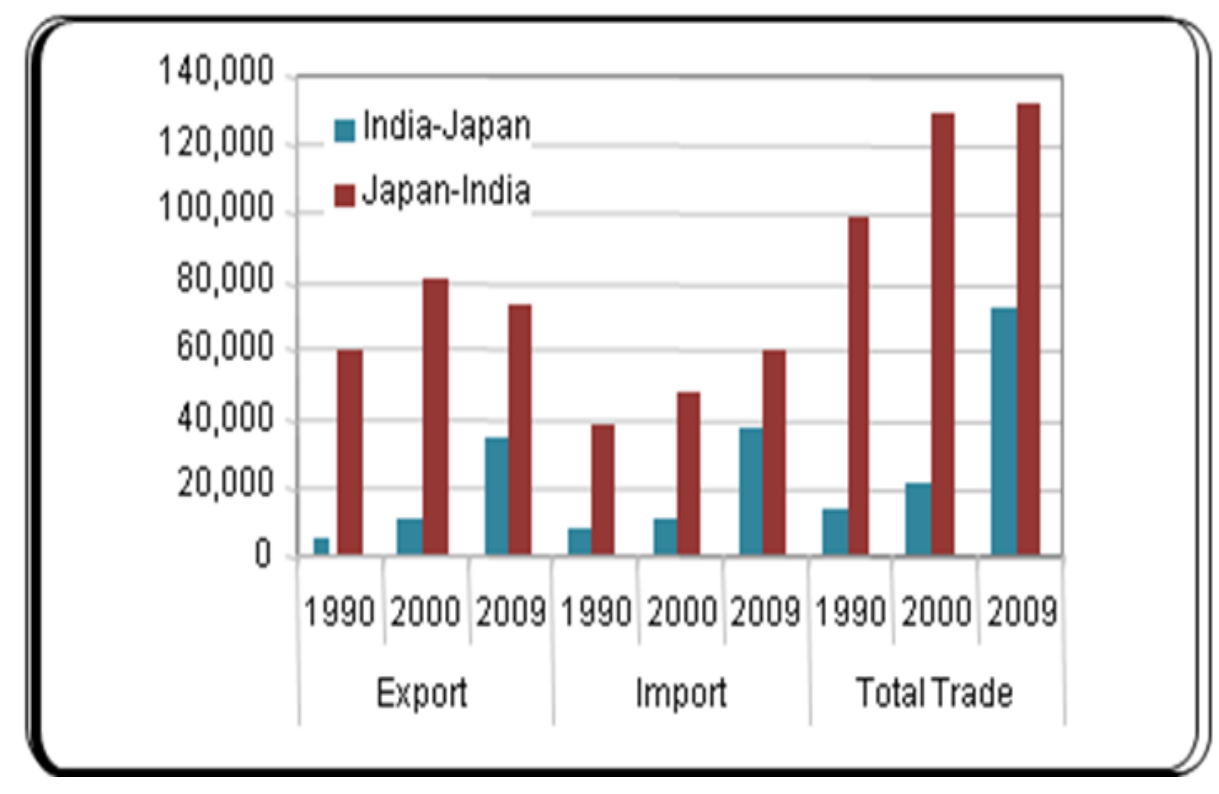

Source: CEIC Database (2010) 
Table 3: India's Top Ten Exports to Japan $(1990,2000,2008)$

\begin{tabular}{|c|c|c|c|c|c|c|}
\hline & 1990 & & 2000 & & 2008 & \\
\hline Rank & Commodity & $\%$ & Commodity & $\%$ & Commodity & $\%$ \\
\hline 1 & $\begin{array}{l}\text { Jewellery, works of } \\
\text { art }\end{array}$ & 17.34 & $\begin{array}{l}\text { Meat } \\
\text { Jewellery, works of }\end{array}$ & 10.79 & $\begin{array}{l}\text { Refined petroleum } \\
\text { products }\end{array}$ & 12.55 \\
\hline 2 & Iron ores & 11.41 & art & 9.54 & $\begin{array}{l}\text { Iron ores } \\
\text { Jewellery, works of }\end{array}$ & 4.95 \\
\hline 3 & $\begin{array}{l}\text { Meat } \\
\text { Non-edible }\end{array}$ & 6.73 & $\begin{array}{l}\text { Iron ores } \\
\text { Refined petroleum }\end{array}$ & 6.94 & art & 3.36 \\
\hline 4 & $\begin{array}{l}\text { agricultural prod. } \\
\text { Unprocessed }\end{array}$ & 1.93 & products & 4.58 & Iron Steel & 3.25 \\
\hline 5 & minerals n.e.s. & 1.89 & Clothing & 2.33 & Animal food & 3.12 \\
\hline 6 & $\begin{array}{l}\text { Clothing } \\
\text { Other edible }\end{array}$ & 1.81 & Yarns fabrics & 2.07 & Non ferrous ores & 2.94 \\
\hline 7 & agricultural prod & 1.71 & $\begin{array}{l}\text { Carpets } \\
\text { Other edible }\end{array}$ & 1.41 & $\begin{array}{l}\text { Meat } \\
\text { Basic organic }\end{array}$ & 2.66 \\
\hline 8 & Iron Steel & 1.7 & $\begin{array}{l}\text { agricultural prod } \\
\text { Basic organic }\end{array}$ & 1.36 & chemicals & 2.54 \\
\hline 9 & Leather & 0.88 & $\begin{array}{l}\text { chemicals } \\
\text { Non-edible }\end{array}$ & 1.19 & Clothing & 1.58 \\
\hline 10 & Non ferrous ores & 0.79 & agricultural prod. & 1.09 & Yarns fabrics & 1.15 \\
\hline
\end{tabular}


Table 4: Japan's Top Ten Exports to India, 1990, 2000, 2008

\begin{tabular}{|c|c|c|c|c|c|c|}
\hline & 1990 & & 2000 & & 2008 & \\
\hline Rank & Commodity & $\%$ & Commodity & $\%$ & Commodity & $\%$ \\
\hline 1 & Iron Steel & 4.74 & Engines & 8.41 & Iron Steel & 4.52 \\
\hline 2 & $\begin{array}{l}\text { Engines } \\
\text { Specialized }\end{array}$ & 4.6 & Miscellaneous hardware & 4.88 & Machine tools & 4.41 \\
\hline 3 & $\begin{array}{l}\text { machines } \\
\text { Basic organic }\end{array}$ & 3.78 & Vehicles components & 3.5 & Engines & 4.29 \\
\hline 4 & $\begin{array}{l}\text { chemicals } \\
\text { Miscellaneous }\end{array}$ & 3.14 & Iron Steel & 2.83 & $\begin{array}{l}\text { Specialized machines } \\
\text { Refined petroleum }\end{array}$ & 3.77 \\
\hline 5 & $\begin{array}{l}\text { hardware } \\
\text { Vehicles }\end{array}$ & 3.06 & Basic organic chemicals & 2.79 & $\begin{array}{l}\text { products } \\
\text { Miscellaneous }\end{array}$ & 3.66 \\
\hline 6 & components & 2.66 & Electrical apparatus & 2.56 & hardware & 3.39 \\
\hline 7 & $\begin{array}{l}\text { Electrical apparatus } \\
\text { Precision }\end{array}$ & 2.5 & $\begin{array}{l}\text { Specialized machines } \\
\text { Miscellaneous manuf. }\end{array}$ & 2.23 & $\begin{array}{l}\text { Vehicles components } \\
\text { Construction }\end{array}$ & 2.51 \\
\hline 8 & instruments & 2.4 & articles & 2.09 & equipment & 2.51 \\
\hline 9 & $\begin{array}{l}\text { Tubes } \\
\text { Electronic }\end{array}$ & 1.88 & Precision instruments & 2.02 & Electrical apparatus & 2.17 \\
\hline 10 & components & 1.79 & Machine tools & 2 & Precision instruments & 2.11 \\
\hline
\end{tabular}

Source: CHELEM

\section{Previous Studies}

Though there have been some studies on the impact of proposed FTA between BIMSTEC and Japan (Strutt, 2008; Bhattacharya and Bhattacharyay, 2007), study specific to India and Japan is rare in the literature.

A study by Kalirajan and Bhattacharya (2008) made an empirical estimation of trade potential by 10 sectors or commodity groups. In terms of indices of export efficiency ${ }^{6}$ for major 10 commodity groups, India has achieved, on an average only 60 percent of its potential, while Japan has achieved 64 percent. The trade potential results show that India's competitive edge is often in raw materials while that of Japan consist of nuclear reactors, boilers and machines, transport related vehicles and electrical machinery and equipment. Moreover, the study suggests that a bilateral free trade agreement, if only tariff-based, would probably not have a

\footnotetext{
${ }^{6}$ The index indicates the effective negative influences of "behind the border" constraints (under the control of home country; other than tariffs and NTBs) for the existing levels of implicit "beyond the border" constraints (those under control of partner countries) on export flows between countries.
} 
significant impact for India as Japan's average tariff is quite low compared to that of India. Better results can be expected if the FTA also involves non-tariff barriers (NTB) which include technical barriers such as various issues regarding standards, technical regulations and conformity assessment procedures) as illustrated in sanitary and phytosanitary measures (SPS) to trade.

Recently a work has been done by Ahmed (2010) to investigate the potential economic impacts of prospective India- Japan FTA in goods using partial equilibrium (SMART) model and Global computable general equilibrium (GTAP) model. The results reveal that both India and Japan's consumer's surplus will be increasing as result of this FTA. However, the GTAP analysis shows that India-Japan FTA would result in welfare loss for India while positive welfare gains for Japan. This study also indicates the possibility of increase in bilateral exports. The simulation exercises are done on 2004 data of GTAP Version 7 without considering any future projection.

\section{Framework of the CGE Analysis}

To estimate the impact of proposed trade agreement between India and Japan at 2020, the paper has used a widely recognized model called global CGE shortly GTAP.

In brief the structure of the GTAP model (for details see Hertel, 1997; Mukhopadhyay and Thomassin 2010a) includes industrial sectors, households, governments and global sectors (transport and banking) across countries. Countries and regions in the world economy are linked together through trade. Prices and quantities are simultaneously determined in both factor markets and commodity markets. Five factors of production are included in the model: labour- Skilled and Unskilled, capital, natural resource and land. In the model, firms minimize the cost of inputs given their level of output and fixed technology. The production functions used in the model are of a Leontief structure. This means that the relationship between fixed and intermediate inputs is fixed. Similarly, the relationship between the amount of intermediate inputs and outputs is also fixed. Firms can purchase intermediate inputs locally or import them from other countries.

Household behaviour in the model is determined with an aggregate utility function. This utility function includes private consumption, Government consumption and savings. Current Government expenditures are covered by the regional household utility function as a proxy for Government provision of public goods and services.

Domestic support and trade policy (tariff and non-tariff barriers) are modelled as ad valorem equivalents. These policies have a direct impact on the production and consumption sectors in the model. Changes in these policies have an impact on the production and consumption decisions of sectors in the model.

There are two global sectors in the model: transport and banking. The transport sector takes into account the difference in the price of a commodity as a result of the transport of the good between countries. The global banking sector brings into equilibrium savings and investments in the model.

In equilibrium, all firms have zero real profit, all household expenditures are within their budget, and global investments equal global savings. Changing the model's parameters allows one to 
estimate the impact from a country's or region's original equilibrium position to a new equilibrium position.

Closure plays a very important role in GTAP modelling. Closure is the classification of the variables in the model as either endogenous or exogenous variables. Endogenous variables are determined (solved for) by the model and exogenous variables are predetermined outside the model and can therefore be changed from the outside, or shocked. Closure can be used to capture policy regimes and structural rigidities. The closure elements of GTAP can include population growth; capital accumulation, including FDI; industrial capacity; technical change; and policy variables (taxes and subsidies).

The number of endogenous variables has to equal the number of equations. This is a necessary but not sufficient condition for a solution. It may be general equilibrium (GE) or partial equilibrium (PE) depending on the choice of the exogenous variables. The standard GTAP closure has the following characteristics: all markets are in equilibrium, all firms earn zero profits and regional household expenditures are on budget constraint.

\section{Data and Scenario Development}

Version 7 of the GTAP model and database based on 2004 is used to undertake the analysis (Narayanan and Walmlessly, 2008). This version of the model includes 57 commodities (sectors) and 113 regions. The 57 industrial sectors have been aggregated to 28 sectors in each country and region. The 113 regions are aggregated into 7 regions, with an emphasis on the countries under current exercise. This aggregation includes two individual countries -India and Japan, and five other regions- Rest of OECD, ASEAN, PRC, Rest of Asia and Rest of the world. Data for 28 sectors were included for all regions in the model.

Here two scenarios have been attempted: a) Business as Usual, b) Tariff Reduction Scenario. The year 2004 is used as base year and apply macroeconomic shocks — changes in the values of the macroeconomic variables (GDP, population, skilled and unskilled labor, and capital) to generate a new economy for 2010, and 2020. In this analysis the tariff structure for all regions and countries remained unchanged from 2004. This Business As Usual (BAU) remains the same throughout the analysis and is the base from which the other scenarios will be compared. The tariff reduction has been done for India and Japan, while rest of the regions is not under agreement.

The simulation exercise describes scenario reductions in import tariffs within India and Japan considering selected sectors. The sectors are identified on the basis of recent informal and formal negotiations between India and Japan and also the trade intensiveness as discussed earlier. The reduction rate for agriculture and industrial sectors is 100\% applied within 2020.

The above scenario description requires a change in the development of the GTAP model to undertake the analysis. In this case, the up-dating of the model to 2020 would require two discrete steps (2004-2010, 2010-2020). There are two general approaches to up-dating the model; a recursive process and the use of dynamic GTAP. For this work, recursive updating process was considered. 
The recursive updating process is based on forecasting the economies of the countries and regions by exogenously shocking the baseline model with projections of selected macroeconomic variables. These projections of the macroeconomic variables are taken from various sources (for details see Mukhopadhyay and Thomassin, 2010; Dimaranan, et al., 2007, UN2006, World Bank 2007) to predict the future direction and strength of an economy. Total factor productivity is endogenously determined to accommodate the combination of these exogenous shocks. This approach allows one to predict the level and growth of GDP as well as trade flows, input use, welfare and the wide range of other variables. Instead of considering capital accumulation, the extra change in investment in $\mathrm{t}^{\text {th }}$ period resulting from trade liberalisation shocks along with the baseline capital forecast for $t+1$ was added.

Moreover, the current study considers the constant Armington elasticity. In terms of policy implications, the constant Armington elasticity undervalues the effects of a policy change around 3 or 4 times compared to the importer-specific Armington elasticities (Yilmazkuday, 2009). However, it depends on the type of commodities traded, long run or short run changes in trade policy and so on.

The GTAP model simulates the impact of trade liberalization (reductions in import tariffs and export subsidies). It estimates how trade flows will change as import tariff restrictions and export subsidies are reduced. As the trade flow between countries changes as a result of trade liberalization, economic growth will be impacted, so will be sectoral output, trade and welfare.

\section{Impact of Proposed India-Japan CEPA: A CGE Analysis}

In this section, the impact of the proposed CEPA between India and Japan will be evaluated using a CGE analysis.

Growth of output. Table 5 records the baseline projection of the global economy and the simulated result of the tariff reduction between India and Japan during 2010-2020. An interesting feature is observed. The growth rate varies across regions in business as usual case. Rest of the world (ROW) has shown highest growth $(70.58 \%)$ followed by ASEAN (61.78\%) and PRC (55.24\%) while moderate growth rate is observed for India (35.05\%), Rest of Asia (34.53\%), Rest of OECD (28.83\%) and the lowest for Japan (9.07\%) during 2010-20. 
Table 5. Output Growth of India and Japan and Other Regions of the World: BAU 20102020 vs. Tariff Reduction Scenario

\begin{tabular}{lrr}
\hline Country/Group & $\begin{array}{c}\text { Baseline: } \\
\text { BAU2010 to BAU2020 } \\
\text { (\% change) }\end{array}$ & $\begin{array}{c}\text { Simulation: } \\
\text { Tariff Reduction } \\
\text { (\% change) }\end{array}$ \\
\hline Rest of OECD & 28.83 & -0.00034 \\
Japan & 9.067 & 0.681 \\
ASEAN & 61.78 & 0.0031 \\
Rest of Asia & 34.53 & 0.0061 \\
PRC & 55.24 & 0.0095 \\
India & 35.051 & 0.1464 \\
7 ROW & 70.58 & 0.0017 \\
Total & 34.014 & 0.0078 \\
\hline
\end{tabular}

Source: Results from the study

With import tariff reduction, there is no significant change in the output growth of the seven regions. A marginal increase in growth for India (0.15\%) and Japan (0.68\%) is observed in 2020 after tariff reduction compared to BAU. Though marginal, PRC will have a better performance compared to ASEAN and Rest of Asia. Rest of OECD will experience a negative growth.

As expected, countries and regions included in the bilateral trade agreement have increased their output, while regions not included in the regional trade agreement may be loser or gainer. The reason behind this impact is as follows. A reduction of tariff on import lowers the import price. Domestic users immediately substitute away from competing imports. The cheaper imports results in a substitution of imports for domestic product. The price of imports falls thereby increasing the aggregate demand for imports. It lowers the price of intermediate goods which causes excess profits. This, in turn, induces output to expand. This expansion effect would impact the demand for primary factors of production resulting in changes in their prices and transmitting the shocks to other sectors in the economies under trade reforms.

\section{Export growth}

The performance of total export reflects wide variations in the growth of the total export of the seven regions under BAU scenario (Table 6). India is expected to achieve highest growth (149.02\%) followed by PRC (147.38\%), ROW and ASEAN. On the other hand, Rest of Asia, Rest of OECD and Japan are in the range of 20-45\% under BAU (2010-20). The tariff reduction scenario between India and Japan reveals $0.04 \%$ total export growth for the world. A marginal export growth is expected due to trade liberalisation strategies taken by India and Japan compared to BAU 2020. For India and Japan, it is estimated as $0.28 \%$ and $0.33 \%$ respectively. Other regions of the world are expected a very insignificant export growth due to India and Japan trade liberalization case. However, PRC's export growth will be better $(0.15 \%)$ compared to those of ASEAN and Rest of Asia (0.01\%). 
Table 6. Export Growth of India and Japan and Other Regions of the World: BAU 20102020 vs. Tariff Reduction Scenario

\begin{tabular}{lrr}
\hline Country/Group & $\begin{array}{c}\text { Baseline: } \\
\text { BAU2010 to BAU2020 } \\
\text { (\% change) }\end{array}$ & $\begin{array}{c}\text { Simulation: } \\
\text { Tariff Reduction } \\
\text { (\% change) }\end{array}$ \\
\hline Rest of OECD & 31.37 & -0.005 \\
Japan & 23.7 & 0.28 \\
ASEAN & 71.5 & 0.01 \\
Rest of Asia & 44.87 & 0.01 \\
PRC & 147.38 & 0.15 \\
India & 149.02 & 0.33 \\
ROW & 84.824 & 0.019 \\
Total & 52.67 & 0.04 \\
Source: Results from the study & &
\end{tabular}

The direction of exports in India and Japan under tariff reduction compared to BAU shows more insight into the analysis (tables 7,8 ). Normally in bilateral tariff reduction scenario both the economies will be benefited within themselves but the impact on other regions may be or may not be favourable (Mukhopadhyay and Thomassin, 2008).

A look at the trade diversion resulting from the tariff cut between India and Japan reveals that exports of India and Japan are diverted from other regions and increase within themselves. For example, India's and Japan's export has been withdrawn from all other regions of the world under study (except PRC in case of Japan's export). The creation of trade as such is marginal for both the countries. However, the significant trade creation within these two countries is expected to occur. As a result of the proposed agreement between two countries, India would likely to increase its export to Japan by $18.25 \%$ (table 8), while for Japan it will be only 4.65\% (table 14) by 2020. To get more access to Japan's market, India would shift its market from other countries to Japan and so also Japan. Moreover, it is also seen that Japan will not reduce its heavy reliance on the Chinese market, though India will. This is one of the important findings of the proposed agreement between India and Japan from our study, which the policy makers have to reckon with. On the whole, it reflects that compared to Japan, India is expected to gain more, if CEPA materializes by 2020. 
Table 7. Direction of Trade between Japan and All Regions: BAU 2010-2020 vs. Tariff Reduction Scenario

\begin{tabular}{lrr}
\hline Country/Group & $\begin{array}{c}\text { BAU2010 to BAU2020: } \\
\text { (\% change) }\end{array}$ & $\begin{array}{c}\text { Simulation: } \\
\text { Tariff Reduction } \\
\text { (\% change) }\end{array}$ \\
\hline Rest of OECD & 21.434 & -0.32 \\
ASEAN & 19.614 & -0.32 \\
Rest of Asia & 13.083 & -0.27 \\
PRC & 8.69 & 0.013 \\
India & 134.85 & 4.65 \\
ROW & 80.098 & -0.24 \\
Total & 23.7 & 0.28 \\
\hline
\end{tabular}

Source: Results from the study

Table 8. Direction of Trade between India and All Regions: BAU 2010-2020 vs. Tariff Reduction Scenario

\begin{tabular}{lrr}
\hline Country/Group & $\begin{array}{c}\text { Baseline: } \\
\text { BAU2010 to BAU2020 } \\
\text { (\% change) }\end{array}$ & $\begin{array}{c}\text { Simulation: } \\
\text { Tariff Reduction } \\
\text { (\% change) }\end{array}$ \\
\hline Rest of OECD & 150.22 & -0.22 \\
Japan & 108.41 & 18.21 \\
ASEAN & 129.84 & -0.2 \\
Rest of Asia & 110.85 & -0.14 \\
PRC & 61.56 & -0.11 \\
ROW & 194.15 & -0.03 \\
Total & 149.02 & 0.33 \\
\hline
\end{tabular}

Source: Results from the study

The outcome is generally expected from the trade creation and trade diversion effects of trade reforms. The magnitude of impacts on the countries and regions differ, depending first on their size and comparative advantage (resource endowments) and also on the other factors such as demand structure, distribution structure and so on. In terms of sectoral output growth, the motors, vehicles and parts industry will benefit most for Japan, while it is the light manufacturing industry for India (table 9). 
Table 9. Percentage Change in Sectoral Output after Tariff Shock at 2020 Compared to BAU 2020

\begin{tabular}{llll}
\hline \multicolumn{1}{c}{ Japan } & & \multicolumn{2}{c}{ India } \\
\hline Ferrous metals & 1.11 & Forestry & 1.26 \\
Metal products & 0.24 & Light Manufacturing & 1.84 \\
Motor vehicles and parts & 2.14 & Chemical,rubber, plastic prods & 0.12 \\
Transport equipment nec & 0.21 & Mineral products & 0.44 \\
Electronic equipment & 0.75 & Ferrous metals & 0.34 \\
Machinery and equipment nec & 0.54 & Metal products & 0.33 \\
& & Motor vehicles and parts & 0.32 \\
\hline
\end{tabular}

Source: Results from the study

The sectoral export performance due to liberalization of trade between the countries at 2020 will provide more insight in this respect (table 10). The common key sectors between countries are chemical rubber and plastics, light manufacturing, metals nec (non ferrous metals), electronic equipment, manufacturing equipment and motor vehicles and parts. The percentage share of export for these products from Japan is expected to be higher compared to India. The key sectors belong to both export and output for both the countries are chemical rubber and plastics, electronic equipment and motor vehicles.

Table 10 Percentage Change in Sectoral Export after Tariff Shock at 2020 Compared to BAU 2020

\begin{tabular}{|l|r|l|r|}
\hline Japan to India & & $\begin{array}{l}\text { India to } \\
\text { Japan }\end{array}$ & \\
\hline 12 LightMnfc & $\begin{array}{r}15.9 \\
9\end{array}$ & $\begin{array}{l}\text { 12 Light } \\
\text { Mnfc }\end{array}$ & 7.68 \\
\hline 13 p_c & 7.92 & 4 forestry & 7.06 \\
\hline 14 CRP & 5.55 & 14 CRP & 3.04 \\
\hline 16 ferrous & 1.98 & $\begin{array}{l}17 \text { metals } \\
\text { nec }\end{array}$ & 0.34 \\
\hline 17 metals nec & 21.1 & $\begin{array}{l}18 \text { metal } \\
\text { prod }\end{array}$ & 0.073 \\
\hline 19 mvh & 2.21 & 19 mvh & 0.013 \\
\hline 20 otn & 0.84 & 21 ele & 0.09 \\
\hline 21 ele & 2.74 & 22 ome & 0.11 \\
\hline 22 ome & 2.26 & 23 omf & 0.14 \\
\hline
\end{tabular}

Source: Results from the study 


\section{Welfare effect ${ }^{7}$}

In global CGE model each region's representative agent aims to maximize his/her welfare level. When trade policy is changed the agent will calculate a change in his/her income level. The change income level affects the scale of savings and consumption of each commodity so that the marginal utility of consumption is same across the commodities. In this case price variables are used in the decision making process for clearing markets in the model. While the welfare level of representative agents in trade agreement member countries (here India and Japan) would improve, the welfare level of agents in other regions (here five regions) would likely to decline. Since each region's welfare function is different the impact of trade reforms between India and Japan on welfare level of seven economies would likely to be different.

Table 11 summarizes the results of welfare effect across seven regions. Gains or losses are not spread evenly. It can be observed that in case of tariff reduction, the welfare of India and Japan responded differently. India's welfare gain is expected to be 120.27 million USD, while Japan's would be by 1198.67 million USD. All the other regions will experience welfare loss. And net global welfare would decrease by 194.72 million USD.

Table 11. Welfare Implications due to Proposed Trade Agreement between India and Japan

\begin{tabular}{lrrrr}
\hline Country/Group & $\begin{array}{c}\text { Allocative } \\
\text { Efficiency Effect }\end{array}$ & $\begin{array}{c}\text { Terms of Trade } \\
\text { Effect }\end{array}$ & $\begin{array}{r}\text { Investment-Savings } \\
\text { Effect }\end{array}$ & \multicolumn{1}{c}{ Total } \\
\hline Rest of OECD & -241.71 & -530.53 & -306.36 & -1078.61 \\
Japan & 281.13 & 1034.91 & -117.38 & 1198.67 \\
ASEAN & -31.59 & -107.23 & -14.12 & -152.95 \\
Rest of Asia & -3.28 & -49.69 & -14.65 & -67.62 \\
PRC & -24.51 & -400.91 & 294.41 & -131.01 \\
India & -132.25 & 33.73 & 218.79 & 120.27 \\
ROW & -41.91 & 19.08 & -60.64 & -83.47 \\
Total & -194.12 & -0.65 & 0.05 & -194.72 \\
\hline
\end{tabular}

Source: Authors

The welfare effects are measured using the equivalent variations (EV). The welfare decomposition result provides further insight into the analysis. The welfare gains from a bilateral liberalization are fundamentally determined by two factors: a) the change in efficiency with which any given economy utilizes its resources; and b) changes in a country's terms of trade, which allow to calculate the regional equivalent variation or the amount of money that could be

\footnotetext{
${ }^{7}$ In GTAP framework, the sources of welfare gains can be examined by decomposing welfare gains into three components, namely, a) Allocative efficiency, b) terms of trade effects and c) Investment-Savings effect. Allocative efficiency refers to the efficient industry wise allocation of scarce resources to produce the optimal combination of outputs. The terms of trade effect refers to the relative movement in prices of countries' exports and imports. The TOT effect increases with a relative increase in the price of exports as compared to that of imports. TOT changes occur as producers and consumers adjust their purchasing and selling patterns in response to a policy change. Finally the investment-Savings effect refers to impacts of changes in the price of investment (capital goods) and savings.
} 
taken away from consumers at initial prices while leaving them at the same level of post simulation utility. If a particular country experiences an improvement in its terms of trade i.e., export price rise relative to import price, then the equivalent variation gain will be larger than the efficiency gain. If the terms of trade deteriorate then the opposite will happen. Table 11 shows that TOT improves significantly for Japan and allocative efficiency is positive. On the other hand, though the TOT is marginal for India but allocative efficiency is negative. This bilateral agreement between India and Japan may also lead to an adverse impact on terms of trade and allocative efficiency for the other regions of the world.

Overall welfare results indicate that trade liberalization lead to welfare level improvement in case of partner countries at the expense of non-agreement countries resulting in a net loss in global welfare. More specifically, the welfare gains in India and Japan under FTA are not sufficient to offset the losses in other countries, which results in a net global welfare loss. It shows that the non agreement countries are expected to have loss due to allocative efficiency after liberalization as the removal of distortion leads to a reallocation of resources from the efficient to the more inefficient sectors. The tariff liberalization in agriculture sector will have positive impact on welfare in Japan, even though agricultural sector in Japan is very much sensitive.

An important aspect of our finding is related to the agriculture sector in Japan. Although Japan is a large importer of agriculture products, the country has traditionally been very sensitive about its agriculture sector and continues to protect this sector with stringent tariff and nontariff barriers. Our analysis demonstrates that in spite of tariff liberalization in agriculture sector, Japan will witness considerable welfare gain. These results will justify the gradual opening up of Japanese agricultural sector.

Our study is sharply contrasted with Ahmed (2010) in context of welfare implications between India and Japan FTA. The proposed FTA will improve the welfare of both the countries at 2020, while Ahmed (2010) finds it for Japan only, not for India. Moreover, our study found that India's export to Japan would increase more than that of Japan to India, whereas Ahmed (2010) shows opposite.

In this connection we can also refer some of the findings of growing literatures in this field. An analysis of the economic effects of Japan-Republic of Korea FTA has been attempted by Nakajima (2002) to see the short run as well as long run impacts using GTAP model. Republic of Korea's real GDP would increase in the long run. On the other hand, gains for Japan would likely to be limited in terms of real GDP. However, both countries would gain from welfare. McKibbin, Lee, and Cheong (2004) estimated that gains for Korea and Japan from a bilateral FTA would also amount to $0.1-0.2 \%$ of GDP per year for both countries. The study by Cheong (2002) between Republic of Korea, Chile and Japan using GTAP shows that despite many obstacles, a Republic of Korea-Japan FTA would offer various economic benefits. However, the effects of Chile would be moderate. A study by Hartono, Priyarsono, Nguyen, and Ezaki (2007) found that most of FTAs between Indonesia and China, Indonesia and Japan will have positive impacts on GDP, welfare, investment, trade, with varying degree of benefits.

Lochindaratn (2008) performs the impact analysis of certain bilateral preferential trading agreements of Thailand with Japan, China, India, Australia, and New Zealand using GTAP. 
Result shows that Japan-Thailand Economic Partnership Agreement (EPA) is the most beneficial while Thailand New Zealand China EPA turns out to be the least beneficial FTA for Thailand. Real gains from bilateral FTAs are poor compared to the benefits from the groupings that include ASEAN as a whole. Strutt and Rae (2007) argue that multilateral trade negotiations have faced many hurdles and frustrations in recent years, giving increased impetus for some countries to negotiate regional and bilateral trade agreements. They explore how preferential trade agreements might impact on one another. They use the dynamic GTAP model to assess the anticipated impact of possible liberalization scenarios. Results reveal that China-New Zealand agreement is unlikely to have a large economic impact on China, significant gains may accrue to New Zealand, particularly if there is liberalization of the sensitive agricultural sector. However, if China also enters into preferential agreements with other countries, this is likely to have adverse impact on the gains accruing to New Zealand.

A very recent work by Gumilang, Mukhopadhyay and Thomassin (2011) provides further insight in this area with a study on Indonesia and its trade agreements with Japan (IJEPA) and ASEAN (AFTA). A static global CGE model was used to project the Indonesian economy to the year 2022, with and without tariff reforms agreements. Results show that the agreements will have a marginal positive impact on Indonesia's output but with a noticeable increase in trade flows and signs of trade diversion. Overall AFTA has a greater impact on the Indonesian economy compared to IJEPA.

\section{Conclusion}

The present study evaluates the economy wide impact of the proposed CEPA between India and Japan at 2020. The study has used a widely recognized global CGE model.

Results of the CGE analysis on the economy-wide impact of CEPA suggests that tariff reduction will create a marginal increase in output growth for both India and Japan as compared to business as usual (BAU) scenario. In terms of effect on exports, India's export to Japan would increase significantly, more than that of Japan to India. Tariff reduction will increase India's export to Japan by 18.25 percent, while for Japan it will be only 4.65 percent. However, some commodities like metal nec (non ferrous metal), light manufacturing, electronic equipment and motor vehicles and parts will have much larger share in export list of Japan compared to India. As for the welfare aspect, simulation results suggest a positive net welfare gain for both countries with an expected gain of US\$1198.67 million and US\$120.27 million for India and Japan, respectively. Moreover, results suggest that Japan will not reduce its heavy reliance on the Chinese market, though India will. On the whole, India, compared to Japan, will gain more, if CEPA materializes by 2020.

Moreover, results suggest that Japan will not reduce its heavy reliance on the Chinese market, though India will. On the whole, India, compared to Japan, will gain more, if CEPA materializes by 2020 .

Given the current pattern of India-Japan trade, and investment linkages, the need for deeper economic cooperation between two countries becomes more apparent. The fact that bilateral 
trade is steadily growing and yet trade shares are rather small suggests that there is a huge potential for expansion of bilateral trade.

In order to remove behind the border barriers, both countries need to accelerate structural reforms for reaping the maximum benefit of their economic partnership. Among others, India needs to strengthen its infrastructure, policies and regulations, whereas Japan can liberalize its immigration policies and agricultural trade. According to the Goldman Sachs BRIC report, India and Japan are expected to be among the top four economies of the world by 2050 (Wilson and Purushothaman, 2003). With a strong economic partnership between two nations, this goal can be achieved much earlier.

However, forecasts for Japan's economic growth are becoming more and more pessimistic due to recent disaster in Japan. Japan's economic growth, already anemic because of the global recession in 2008-2009, is expected to drop into negative territory for a quarter or two but turn positive again as the crisis passes and rebuilding commences (Nanto et al. 2011). The extent of the damage, ranging between $\$ 122$ billion to $\$ 235$ billion (Bloomberg, 21 March 2011), becomes more apparent, initial expectations were that the disaster would shave 0.2 to 0.5 percentage points off total GDP growth in 2011, but that growth still would be around 1\%. An estimate by IHS Global Insight was for growth in 2011 to be $0.5 \%$ with reconstruction in 2012 increasing it to about $3.5 \%$ (IHS, 2011). Japanese authorities estimated that the rebuilding would cost as much as $\$ 309$ billion (BBC News, 23 March 2011). Morgan Stanley expects a short and deep recession in Japan with the economy shrinking by 1\% to 3\% in 2011 and a reduction in global growth of about 0.5 percentage points (Morgan Stanley, 2011).

According to ADB's Asian Development Outlook 2011, there are likely to be substantial shortrun negative impacts from disruptions in supply and power shortages, but the long-run impacts are less dire as the Japanese economy will turn positive again through reconstruction efforts and return to productive activities. ADB forecasts a $1.5 \%$ and $1.8 \%$ growth rate of the Japanese economy for the years 2011 and 2012 respectively (ADO, 2011).

In view of this, the magnitude of the expected trade benefits of CEPA between India and Japan could be marginally lower or would likely to be delayed. On the other hand, the triple disasters in Japan can also lead towards enhancing economic cooperation between the two countries: for example:

- Japanese companies may expand their existing production capacities and establish new capacities to supplement production loss in Japan.

- Japan can utilize India's production base to maintain its supply chain activities.

- Indian companies from ITC, pharmaceuticals and other hi-tech service sectors can invest in Japan to utilize technology, skill and capitals.

There are many areas of mutually beneficial cooperation between India and Japan. Work should proceed both to enhance areas of advantage and to remove barriers to cooperation and economic integration. Economic and strategic partnership between the two countries should proceed not only bilaterally, but also multilaterally, through opening of markets (such as agriculture and financial markets), integrating financial systems, encouraging free flow of capital and direct investments, and linking economies in a common production chain. While much work is needed to accomplish these goals, the benefits can be large. 
The Japan-India comprehensive economic partnership can focus on trade, democratic development, energy security, environment and climate change, natural and man-made disaster and fighting terrorism, among others. In view of the economic complementarities between the two countries and their common goals and values, this can produce a win-win situation.

\section{References}

ADO (2011) Asian Development Outlook 2011: South South Economic Links, Published by Asian Development Bank, Manila

Ahmed, S. 2010. India-Japan FTA in Goods: A Partial and General Equilibrium Analysis GTAP Resource. 3329. Paper Presented at the 13th Annual Conference on Global Economic Analysis, 9-11 June, Penang, Malaysia.

BBC News. 2011. Japan says quake rebuilding to cost as much as 25tn yen (23 March 2011). Available at: http://www.bbc.co.uk/news/business-12828181 accessed 16 May 2011.

Bhattacharya, S. and B. Bhattacharyay. 2007. Gains and losses of India-China Trade Cooperation-A Gravity Model Impact Analysis. CESifo Working Paper Series 1970. Munich: Center for Economic Studies.

Bloomberg News. 2011. Japan Reconstruction After Earthquake May Last Five Years, World Bank Says (21 March 2011). Available at: http://www.bloomberg.com/news/2011-03-21/japanmay-take-five-years-to-rebuild-after-quake-tsunami-world-bank-says.html accessed 16 May 2011.

CHELEM, 2010. - International Trade Database, http://www.cepii.fr/anglaisgraph/bdd/chelem.htm, accessed in July 2010

CEIC database-Macroeconomic database for emerging and developed markets, http://www.ceicdata.com/

Dimaranan, B., E. Ianchovichina and W. Martin. 2007. China, India and the Future of the World Economy: Fierce Competition or Shared Growth? Policy Research Working Paper 4304.

Economy Watch (2008) Economy Watch. 2008. Japan Economy. 25 June. Available: http://www.economywatch.com/world economy/japan/index.html

Embassy of India in Japan. 2008, 12 July. India at a glance. Available:

http://www.embassyofindiajapan.org/

IHS(2011) IHS Global Insight, Japan: Japan's Earthquake: a Macroeconomic Damage Assessment, Country Intelligence - Analysis, March 24, 2011. 
Kalirajan, K. and S. Bhattacharya. 2008. Analysis of Constraints to Free Trade Agreement between India and Japan. Draft, National Graduate Institute for Policy Studies, Tokyo, and the Indian Institute of Public Administration, New Delhi.

Kawai, M., B. N. Bhattacharyay, and K. Mukhopadhyay (2011) "Forging a Comprehensive Economic Partnership between India and Japan: Impact, Prospects and Challenges" Paper presented at the 9th Biennial Pacific Conference, April 26-29, Brisbane, Australia.

Ministry of Finance, India and Ministry of Foreign Affairs, Japan, 2006. Report of the India-Japan Joint Study Group. Available: http://www.mofa.go.jp/region/asiapaci/india/partner0504.html

Morgan Stanley (2011) MUFG, Tohoku Earthquake: First Assessment, Japan Research, New York, NY, March 22, 2011, p.

Mukhopadhyay, K and P.J.Thomassin. 2010. Economic and Environmental Impact of Free Trade in East and South East Asia, Springer, the Netherlands: 1-209.

Mukhopadhyay, K \& P. J. Thomassin. 2008. Economic Impact of East and Southeast Asian FTAs. Asia Pacific Trade and Investment Review. 4(2) : 57-82.

Nanto, D. K., W. H. Cooper., J. M. Donnelly and R. Johnson(2011) Japan's 2011 Earthquake and Tsunami: Economic Effects and Implications for the United States, CRS Report for Congress, Prepared for Members and Committees of Congress, Congressional Research Service, 7-5700, R41702

Narayanan B. G. and T.L. Walmsley. 2008. Global Trade, Assistance, and Production: The GTAP 7 Data Base, Center for Global Trade Analysis, Purdue University.

Rajamohan, P. G., D. B. Rahut and J.T. Jacob. 2008. Changing Paradigm of Indo-Japan Relations: Opportunities and Challenges. Indian Council for Research on International Economic Relations Working Paper No. 212.

Strutt, A. 2008. Quantitatively Assessing a BIMSTEC-Japan FTA: A CGE Analysis CSIRD Discussion Paper. 40. India: CSIRD.

United Nations. 2006. World Population Prospects: The 2006 Revision Population Database, United Nations Population Division, Population and Economically Active Population (version 5) Department of Economic and Social Affairs of the United Nations Secretariat.

Wilson, D. and R. Purushothaman. 2003. Dreaming with BRICs: The Path to 2050. Global Economics Paper No. 99 .New York: Goldman Sachs 
World Bank. 2007. World Development Indicators, Real Historical and Projected Gross Domestic Product (GDP) and Growth Rates of GDP for Baseline Countries /Regions 2000-2017.

Yilmazkuday, H .2009 Is the Armington Elasticity Really Constant across Importers? MPRA Paper \# 15954, http://mpra.ub.uni-muenchen.de/15954/ 